with a repository of scientific apparatus that would now have the utmost historical value, has neglected and scattered the instruments of its great alumni, Boyle, Wren, Hooke. A fashion has been set of undervaluing scientific treasures left in trust, the latest examples being the dispersal of the Crisp collection of Microscopes, of the Howard Library (by the Royal Society), and of a part of the Library of Sir Isaac Newton.

The Lewis Evans collection has afforded an opportunity of trying to stem the current of our losses, and by the construction of models illustrating certain aspects of the work of the first Oxford fellows of the Royal Society. Models of Wren's perspectograph and level recall his method of dealing with problems presented by the devastated areas in the Metropolis after the Great Fire of I666. A model of Hooke's microscope recalls what was perhaps the greatest achievement of that universally inventive genius, the first discovery of cell structure in living beings. In another case is an exhibit illustrating the first discovery of oxygen in 1668 by John Mayow of Wadham College. A model of Boyle's first airpump reminds us that it was the High Street in Oxford that produced the first English engine to demonstrate the possibility of harnessing the force exerted by atmospheric pressure, the "spring of the air," as Boyle called it. Other models show how the dwellers in an inland town have been able to teach and assist navigators; Hooke's reflecting instrument, Gunter's cross-staff and sector, the magnetic compasses of I269 of Peter Peregrinus, and of $175^{\circ}$ of Gowin Knight of Magdalen College being notable examples, paralleled in our own time by the instruments invented for seamen by Lord Kelvin.

Space will not permit us to rehearse all the exhibits in our small Museum, but in truth we may define it as a school of gratitude to the great men who have increased the knowledge and the power of the human race. The most recent of the reconstructions is a beautifully made astrolabe designed by Prof. Frewen Jenkin, for making known the virtues and uses of that 'mathematical jewel' to a wider public than the favoured few who possess original examples. In this regenerated form, the astrolabe again becomes an instrument of great educational value.

The enterprise of museum founding has not been without its disappointments. First and foremost was the dispersal of the collection formed by Sir Frank Crisp to illustrate the evolution of the microscope.
Through the kindness of Sir John Findlay, one of the masterpieces of that collection, a superb silver instrument by Adams, is on view in Oxford for the meeting of the British Association. But the general disappearance of much good apparatus in Oxford itself is deplorable. Only a few months ago there were in existence things of great scientific interest which have vanished. A model with which Bradley illustrated his discovery of the aberration of light is not now forthcoming. Antique microscopes, barometers, the paraphernalia of the educational methods of a century of preparation for the great scientific advances of to-day, have gone to the scrap heap-destroyed in many cases by the urgent needs of research in hand. In the modern laboratory there is no place in which to store the apparatus of bygone experimenters, even if there were a desire to keep it intact, rather than to make use of its parts.

It is our plea that scientific instruments that are of value, either for beauty of design, for achievement in the laboratory or lecture-room, or for some other good cause, should at least be treated with the respect that is accorded to early editions of printed books in a library, or to pictures in a gallery of art. The destruction of a copy of an old book that has been printed in hundreds and reprinted in tens of thousands, inflicts no great harm on the world of letters, but the loss of a unique instrument obscures the whole meaning of early work. Only by contemporary scientific appliances can we hope to show to future generations the ever-varying fashions and phases of our natural philosophy: and few objects are better worth the effort, for in our northern civilisation, natural science has become of greater consequence than art. To traverse the long galleries of the museums of arts and crafts, and to study their masterpieces, is a dispiriting pilgrimage, for it brings home to one how slight is the influence that such exhibitions exercise in elevating the art of a modern people. Scientific instruments, too, show regression in respect of their art; but they show continuous advance in respect of their science.

All work of preservation is of the utmost value in that it helps to check a tendency to destroy evidences of our own early civilisation, and to remind us that with our now diminished resources, instead of spending large sums on the conservation of relics of antiquity abroad, it may pay better to honour the prophets of our own country.
R.T. G.

\title{
The Oxford Meeting of the British Association.
}

$\mathrm{M}^{\mathrm{H}}$ MBERS of the British Association visiting Oxford during the forthcoming meeting will find themselves in the midst of a south-midland district which is, from the naturalist's point of view, possessed of great and varied interest. Opportunities will be given by means of sectional excursions for gaining such acquaintance as may be possible with the geology of the surrounding country, and with noteworthy features of its characteristic fauna and flora. It is obvious that no extended study of the district can be undertaken in the short time at the disposal of those attending the meeting, but the "Handbook" which will be distributed to all visiting members of the Association will provide them with a summary, under various heads, of what the neighbourhood of Oxford can show in the way of natural features of interest.

This handbook, the work of several authors, each of them a first-rate authority on the subject with which he deals, is being produced under the editorship of Commander J. J. Walker, R.N., and will no doubt take rank as a volume of permanent value. It begins with an account by Mr. H. O. Beckit, director of the School of Geography, of the physiography of the Oxford region, including a definition of its boundaries, and describing its land forms and physical history. Sections are added by Mr. W. G. Kendrew on its climate, by 
Mr. E. T. Leeds on its early and by Mr. H. O. Beckit on its modern settlement. The geology of the area is dealt with by Prof. W. J. Sollas, who devotes his attention mainly to the parts of the great Jurassic system which lie within easy reach of Oxford. Dr. K. S. Sandford contributes an account of superficial deposits, and Mr. A. J. Arkell an appendix on the Corallian Period. Articles follow on the botany, ornithology and entomology of the Oxford country; these have been treated with great thoroughness by Dr. G. Claridge Druce, the Rev. F. C. R. Jourdain, and Commander J. J. Walker respectively; the latter having as collaborators Messrs. W. J. Lucas, A. H. Hamm, E. G. R. Waters, and J. Collins. The spiders have been attended to by Mr. A. W. Pickard-Cambridge, and the land and fresh-water mollusca by the Rev. L. W. Grensted. Among the institutions for which Oxford is famous there are three of special importance for the members of the British Association. The first of these, the great entomological department, which takes its name from the late F. W. Hope, is described by Prof. E. B. Poulton; the Pitt-Rivers Museum of Ethnology is treated of by its curator, Mr. Henry Balfour; and the whole series of these valuable memoirs is wound up by Dr. R. T. Gunther's account of the Old Ashmolean Museum and the Lewis Evans collection of scientific instruments therein housed under his curatorship.

The general excursions to Swindon, Stratford-onAvon, Warwick and Kenilworth, Burford, Fairford and the Cotswolds, Blenheim Palace, and the expeditions by river to Day's Lock, to Abington and to Reading, all have their own objects of interest; but for the special purposes of the naturalist the sectional visits to Fawler, Hanborough and Stonesfield; Kirtlington; Culham, Abingdon and Radley; Aylesbury and Wheatley ; Swindon, Faringdon, etc. ; Boar's Hill ; Shotover and Headington (geology); Tring (zoology); and Swinford Bridge; the Berkshire Downs; Lord Parmoor's beechwoods; Bagley Wood (botany and forestry), will provide the best opportunities for studying the natural features of the district.

Apart from the excursions and exhibits which appeal more directly to the geologist and biologist, there is much in Oxford to engage the attention of visiting members. A special selection of rare and interesting works will be on view in the Bodleian Library, by the courtesy of the librarian; and a similar courtesy will be shown by the authorities of the Radcliffe Library now housed at the Museum. Special visits to colleges have been arranged, each under the direction of a guide competent to explain the historical and architectural interest of these institutions, which are such distinctive constituents of the older Universities. The Lewis Evans collection of historic scientific instruments will be shown and discoursed on by the curator; the Pitt-Rivers ethnological collection will be open to inspection, and a visit will be undertaken to the printing works of the famous Clarendon Press. Not the least popular amongst other attractions will be a demonstration on Port Meadow by the Royal Air Force. Machines of several types, with instruments and other apparatus of special interest, will be parked for inspection; a flying display will take place, and the machines will be seen to leave park and take off by flight for return to their home aerodromes.
Much interest will naturally centre round the University Museum, the early history of which structure has been graphically related by Dr. and Mrs. Vernon in an excellent little book published soon after the jubilee celebration held on October 8 , igo8. To those whose recollections go back to the days when Acland and Ruskin were prominent figures in the University, the main building of the Museum is eloquent of the generous ideals of those distinguished enthusiasts. Nor should it be forgotten that without the support of Pusey and his Tractarian friends the scheme for giving the natural sciences a worthy home in the University might have been indefinitely delayed. It is true that the ideal proposed to himself by Acland, that of ensuring that every one leaving Oxford with a degree should at least have had given to him "a general view of the planet on which he lives, of its constituent parts, and of the relations which it occupies as a world among worlds," has never been realised ; the growing necessity for specialisation, together with other reasons, forbade its accomplishment. But the tree planted with so much hope by Acland, Daubeny and Buckland has borne good fruit, though of a kind scarcely contemplated by its original cultivators. Of late years opposition to the growth of the Museum and its departments has usually taken the form of protest against encroachments on the open space of the University park. But a delimitation of frontier has at last been established by general agreement, and the question may now be taken as settled for very many years to come. On the present occasion the Sections of Mathematics and Physics, Geology, Zoology and Engineering, will be housed in the Museum and its annexes, while Botany will find an appropriate home in the neighbourhood of the venerable "Physic Garden."

F. A. D.

\section{Distinguished Guests from Abroad.}

Usually a number of eminent scientific workers from countries outside the British Empire are invited to be guests of the Association at its annual meeting. We print below some particulars of those who have accepted invitations for the Oxford meeting.

Prof. George David Birkoff, who has occupied the chair of mathematics in Harvard University since 19r9, was born at Overisal, Michigan, in I884. He early engaged in teaching mathematics in the University of Wisconsin; next at Princeton, until I9г2, when he became an assistant professor at Harvard, taking up later the major post. President, in 1925 , of the American Mathematical Society, he has been editor of its Transactions since I920. He is a member of the National Academy of Sciences, Washington. In rgI8 Prof. Birkhoff was awarded the Querini-Stampalia prize of the Royal Institute of Science and Arts, Venice, for researches in dynamics. $\mathrm{He}$ is the author of "Relativity and Modern Physics" (1923).

Dr. Max Born, professor of theoretical physics in the University of Göttingen, is one of the chief exponents of the conceptions of modern physics. A recent work of his, "Vorlesungen über Atommechanik" (1925), has received wide attention and appreciation, and an English translation is in course of preparation.

The ABbé Brecil, D.Litt. (Cambridge), is chief pro- 
fessor at the Institute of Human Palæontology, Paris, the foundation of the late Prince Albert of Monaco. $\mathrm{He}$ is the foremost authority on the art and technique of the palæolithic epoch. Prof. Breuil has collaborated in many important works on prehistoric art, and in general archæology, with MM. Capitan and Peyrony. One of the most illuminating and suggestive of his memoirs (1905) is "La Dégénérescence de Figures d'Animaux en Motifs Ornementaux à l'Époque du Renne." Prof. Breuil made lately a tour through Central Europe, Poland, and Hungary, accounts of which have appeared in L'Anthropologie.

Prof. Douglas Houghton Campbell, botanist, was born at Detroit, U.S.A., in 1859 . He is a foreign member of the Linnean Society, and a member of the National Academy of Sciences, Washington. Professor of botany in the University of Indiana from r 888 until $\mathrm{r} 89 \mathrm{r}$, he has since then occupied a similar chair in the Leland Stanford University, California. Prof. Campbell is the author of several botanical text-books.

Prof. Constantin Carathéodory, University of Munich, mathematician, was born in 1873 . Originally professor of mathematics in the Technical Institute, Hanover, next at Breslau, he afterwards successively occupied professorial chairs in the Universities of Göttingen, Berlin, Smyrna, and Athens. He is Ph.D. Göttingen.

M. Maurice Cauliery, who was born in I868, has been professor of zoology at the Sorbonne, Paris, since I909; formerly he occupied a similar chair in the University of Marseilles. $\mathrm{He}$ is director at the Sorbonne of the Laboratoire d'Évolution des êtres organisés et embryologie générale. A publicist of note, he has written on the universities of the United States, and connected scientific life. Prof. Caullery is a foreign member of the Linnean Society of London.

Prof. Frank Wigglesworth Clarke, chemist, was born at Boston, U.S.A., in 1847 . He was professor of chemistry in Harvard University, 1873-74; afterwards, down to 1883 , he held the chair of chemistry and physics in the University of Cincinnati. From that date Prof. Clarke has been Chief Chemist to the United States Geological Survey, and Honorary Curator of Minerals, United States National Museum. A Chevalier of the Legion of Honour, he is a foreign member of the Geological Society of London, LL.D. Aberdeen, and D.Sc. Manchester. In 1903 the Literary and Philosophical Society of Manchester awarded him its Wilde medal. Prof. Clarke is the author of many papers on geo-chemistry in the U.S. Geological Survey's publications.

Prof. Edwin Grant Conklin, biologist, was born at Waldo, Ohio, in $\mathbf{1} 863$. He graduated at Ohio Wesleyan University, and was (1891-94) professor of biology there. Since 1908 he has occupied the chair of zoology in the University of Princeton. $\mathrm{He}$ is a member of the National Academy of Sciences, Washington. Prof. Conklin is the author of "Heredity and Environment," "Biology and Democracy;" and other works.

M. PierRe Dangeard is professor of botany at the Sorbonne, Paris, and director of the Botanical Laboratory there. $\mathrm{He}$ is a member of the Academy of Sciences, Paris, and an Officer of the Legion of Honour. Prof. Dangeard has been responsible, during many years, for an ever-constant series of memoirs and observations in general botany.

Dr. WALTHER voN Dyck, rector of the Bayerische Technische Hochschule, Munich, is also professor of mathematics in the Institute. $\mathrm{He}$ is the author of numerous papers on analysis, differential equations, and the theory of functions, and has interested himself in the work of the German Museum at Munich.

Prof. Paul Ehrenfest, born in $x 880$ at Vienna, has been, since I9I2, professor of theoretical physics in the University of Leyden. He holds a high position in the ranks of mathematical physicists, and has published many valuable memoirs, particularly ou spectra in relation to atomic structure. He is Ph.D. Vienna.

Prof. James Franck, occupant of the chair of physics in the University of Göttingen, and director of the Physical Laboratory there, is the author of many memoirs of distinction on the atomic theory and its issues. He has collaborated with Dr. Max Born in some of these contributions in the Zeitschrift für Physik.

Prof. Oтto Jaekal, Ph.D. Munich, occupant of the chair of geology and palæontology in the University of Greifswald, was born in $186_{3}$. He is well known in English geological circles, and recently was elected a Foreign Associate of the Geological Society of London. Formerly on the teaching staff of the University of Strassburg, he was afterwards curator of the Geological and Palæontological Museum, Berlin. Prof. Jaekal long rendered signal service as editor of the Palaeontologische Zeitschrift.

Prof. Arthur Edwin Kennelly, who has occupied the chair of electrical engineering in Harvard University since 1902 , was born at Bombay in I86I. Educated at University College School, London, he early trained for service with the Eastern Telegraph Company and was engaged on cable-repairing work in many seas; also at one time he was engineer in charge of submarine cable laying for the Mexican Government. Prof. Kennelly was principal electrical assistant to Mr. T. A. Edison from 1887 until 1892 . He is a Chevalier of the Legion of Honour, an honorary member of the Institution of Electrical Engineers, London, and a member of the National Academy of Sciences, Washington.

Prof. Henry Fairfield Osborn, president of the American Museum of Natural History, was born at Fairfield, Connecticut, in $185 \%$. He graduated at Princeton University, U.S.A. Early in his career he studied at Cambridge under F. M. Balfour, and for some time under Huxley, at the Royal School of Mines, London. Prof. Osborn was this year awarded the Wollaston medal of the Geological Society, when reference was made to his long record of researches on the palæontology of vertebrates. Important publications of his include "The Age of Mammals in Europe, Asia, and North America," and "Men of the Old Stone Age." Prof. Osborn is a foreign member of the Royal Society of London, and a Darwin medallist.

Prof. CARL Runge, of Göttingen, was born in 1856 . Originally one of the professors at the Technical Institute, Hanover, he was appointed (1904) to the chair of applied mathematics in the University of Göttingen. $\mathrm{He}$ is eminent for his classical researches in spectroscopy. In I909-1o, Prof. Runge was at Columbia University, New York, as interchange lecturer. NO. 296I, VOL. I I 8$]$ 
Prof. G. Manne Siec Bahn, who has held the chair of physics in the University of Upsala since 1923, was born in 1886. Formerly he was a professor in the University of Lund. Nobel laureate in physics for I924, an experimentalist of great refinement of method, his chief researches have been in the field of X-ray spectroscopy. He has made a special study of the soft radiations which lie between the ultra-violet and the ordinary X-ray region. Prof. Siegbahn is the author of "The Spectroscopy of X-rays" (Oxford Press, 1925). Published originally (1923) at Berlin, it was translated by Mr. George A. Lindsay, assistant professor of physics in the University of Michigan.

Prof. Frank Lincoln Stevens, botanist, was born at Syracuse, N.Y., in $187 \mathrm{I}$. He studied at Ohio State University and the University of Chicago. He occupied the chair of botany and vegetable pathology in North Carolina College of Agriculture and Mechanical Arts from 1902 until I912, and shortly afterwards was elected professor of plant pathology in the University of Illinois, a post he still fills. He has been for many years head of the department of plant diseases and biologist in North Carolina Agricultural Experimental Station. Prof. Stevens is the author of a standard work, "Plant Disease Fungi."

Dr. Johannes WALTHER, who was born in I860, occupies the chair of geology in the University of Halle-Wittenberg, Halle. Formerly he held a similar chair in the University of Jena. Dr. Walther is a foreign member of the Geological Society of London.

Prof. Henry BaLdwin WARD, zoologist, was born at Troy, N.Y., in 1865 . He is a graduate of Williams College, U.S.A., and he was a post-graduate student at the Universities of Göttingen, Freiburg, and Leipzig. $\mathrm{He}$ was professor of zoology in the University of Michigan from 1899 until I909, and has since that date occupied the chair of zoology in the University of Illinois. He has long been in charge of the biological work of the Michigan Fish Commission on Lake Michigan, and has rendered good service to the United States Fish Commission. Prof. Ward is the author of "Freshwater Biology" (I9I7), and of many monographs and papers, especially in regard to animal parasites and the relations of animals to disease.

Geheimrat WILHELm WiEN, the distinguished physicist, rector of the University of Munich, was born in 1864. Formerly he was professor of physics in the University of Würzburg, having succeeded Röntgen in I900. Whilst working there, Prof. Wien was awarded the Nobel prize for physics (I9II); in that year Madame Curie was given the Nobel prize for chemistry. Prof. Wien accepted the chair of experimental physics at Munich, on leaving Würzburg. It may be recalled that at the meeting of the Association held in Cambridge in roo4. Prof. Wien attended and read a paper entitled " Experiments to decide whether the Ether moves with the Earth."

Prof. Pieter Zeeman, of Amsterdam, was born in 1865. He is a foreign member of the Royal Society of London, and in $\mathbf{I} 922$ was awarded the Rumford medal for his researches in optics. Earlier (I902) Prof. Zeeman was Nobel laureate in physics, jointly with Prof. H. A. Lorentz.

Limitations of space do not allow extension of the above brief notices, but we may add that other prominent European men of science attending the meeting include M. von Frey, professor of psychology, University of Würzburg, Dr. D. Nys A. Michotte, professor of psychology in the University of Louvain, Prof. E. Rignano, Milan, Prof. H. Kniep, occupant of the chair of botany in the University of Berlin, Dr. Bosch Gimpera, University of Barcelona, the leading archæologist of northern Spain, M. Champy, professor of histology in the University of Paris, Dr. J. A. Christiansen, professor of chemistry in the University of Copenhagen, and Prof. H. ter Meulen, of Delft.

\section{Obituary.}

Sir Peter Scott Lang.

$\mathrm{W}^{\mathrm{s}}$ E learn with regret that Sir Peter Redford Scott Lang died on July 5 at his residence at Mansefield, St. Andrews. Owing to failing health, in I92I he had retired from the chair of Regius professor of mathematics in the United College at the University of St. Andrews, being given the title of emeritus professor, while he ever continued to show an alert and sympathetic interest in the town and college which he loved and served.

Born in Edinburgh on October 8, I850, Sir Peter received his early education at the Institution and then studied at the University there, where he performed brilliantly in spite of the interruptions to his college work caused by the need to spend considerable time in an office. As a student so circumstanced and yet so successfully overcoming the difficulties of his twofold task, he won first the notice and later the esteem and lasting friendship of the late Prof. P. G. Tait, who appointed him in 1872 to be his assistant in natural philosophy at the University of Edinburgh.

In those days the graduate in arts was seldom proficient or even interested in the sciences; and it was notable how this youthful assistant soon acquired a wide and accurate knowledge of these fields, inspired as he was by the example of Prof. Tait. These two friends co-operated both in classroom and in the work of the Royal Society of Edinburgh, where under this guidance the younger man received much useful experience, and where in 1878 he was made a fellow.

The next year Sir Peter was called to the chair of mathematics in St. Andrews, which had just been vacated by Chrystal, who was migrating to Edinburgh. From I879 until I92I Scott Lang held this post with marked distinction. He devoted himself both to his teaching and also to the wider interests of college life. In this venerable University, affiliated indeed to Bologna, the oldest of medieval universities, new life was wanting. Chrystal had scarcely spent long enough time there to make his influence felt; but during the service of his successor a regeneration took place. He sought to regain that spirit of comradeship among the students which was lacking, and, thanks very largely to his unsparing energies, St. Andrews regained much of the charm and distinction which are the incidental gifts that one of the older universitjes bestows on its

No. 296I, VOL. II 8 ] 